\title{
In Vivo Metabolism of Complement
}

\section{METABOLISM OF THE THIRD COMPONENT ( $\mathrm{C}^{\prime} 3$ ) IN ACQUIRED HEMOLYTIC ANEMIA}

\author{
Lawrence D. Petz, Diane J. Fink, Elizabeth A. Letsky, \\ H. Hugh Fudenberg, and Hans J. Müller-Eberhard \\ From the Hematology Research Laboratory, Veterans Administration Hospital, \\ San Francisco, California 94121; the Department of Medicine, University of \\ California, San Francisco, California 94122, and the Department of \\ Experimental Pathology, Scripps Clinic and Research Foundation, \\ La Jolla, California 92037
}

A в S T R A C T The in vivo metabolism of purified third component of complement labeled with ${ }^{125}$-iodine $\left(\mathrm{C}^{\prime} 3{ }^{125} \mathrm{I}\right)$ was studied in normal subjects and in patients with acquired hemolytic anemias. 27 such studies were performed; in addition, three studies were performed using $C^{\prime} 3 \mathrm{i}$, the biologically inactive reaction product of $\mathrm{C}^{\prime} 3$.

In normal subjects the mean fractional catabolic rate of $\mathrm{C}^{\prime} 3$ was $2.12 \% / \mathrm{hr}$ and the normal range (defined throughout as the mean $\pm 2 \mathrm{sD}$ ) was from 1.56 to 2.68 . The mean percentage of $C^{\prime} 3$ that was intravascular was $66.6 \%$ and the normal range was from 51 to 83 . The $C^{\prime} 3$ synthesis rate averaged $1.16 \mathrm{mg} / \mathrm{kg}$ per hr with a normal range of from 0.90 to 1.42 . The mean serum concentration of $C^{\prime} 3$ was $1.43 \mathrm{mg} / \mathrm{ml}$ with a normal range of from 1.00 to 1.87 .

The fractional catabolic rate and synthesis rate of $C^{\prime} 3$ were at the upper limit of normal or were increased above normal in patients who had warm antibody autoimmune hemolytic anemia with complement on their erythrocytes and in patients with paroxysmal nocturnal hemoglobinuria studied dur-

This work was presented in part at the 10th Annual Meeting of the American Society of Hematology, Toronto, Ontario, Canada, 3-5 December 1967; and abstracted in Blood. 1967. $30: 871$.

Address requests for reprints to Dr. Lawrence D. Petz, Veterans Administration Hospital, 42nd Avenue and Clement Street, San Francisco, Calif. 94121.

Received for publication 11 March 1968 and in revised form 11 July 1968. ing periods of active hemolysis. An increased $C^{\prime} 3$ synthesis rate was also found in one patient who was hematologically normal but had an active peptic ulcer and elevated serum concentration of $\mathrm{C}^{\prime} 3$.

A normal fractional catabolic rate and $\mathrm{C}^{\prime} 3$ synthesis rate were found in patients with autoimmune hemolytic anemia associated with $\alpha$-methyldopa administration, atypical cold antibody autoimmune hemolytic anemia, and in paroxysmal nocturnal hemoglobinuria during an asymptomatic interval.

The three studies with $\mathrm{C}^{\prime} 3 \mathrm{i}^{-{ }^{125}} \mathrm{I}$ revealed a very rapid removal of the labeled protein from the plasma with less than $10 \%$ remaining after $2 \mathrm{hr}$ and with a corresponding increase in urinary excretion rate of the label. The fractional catabolic rate of $\mathrm{C}^{\prime} 3 \mathrm{i}$ averaged $37 \% / \mathrm{hr}$.

The findings are consistent with the previously elucidated in vitro reaction mechanism of $\mathrm{C}^{\prime} 3$ and strengthen the concept that serum complement participates in immune reactions in vivo.

\section{INTRODUCTION}

The human complement system is composed of at least 11 different serum factors or nine numbered components with the first component consisting of three subcomponents (1-3). Low levels of complement occur in some human diseases and complement components bound in vivo have been demonstrated in tissue lesions in patients with glo- 
merulonephritis, lupus erythematosus, amyloidosis, rheumatoid arthritis, and on the surface of erythrocytes of certain patients with acquired hemolytic anemia (1).

In disease states with an underlying immunologic mechanism the demonstration of increased utilization of the components of complement rather than decreased rates of synthesis would constitute important evidence for the concept that complement plays a role in the pathogenesis of at least some manifestations of these diseases. Such studies are now possible, since purification and radioactive labeling without loss of biologic function are feasible with certain of the complement components. The biologic activity of isolated and radio-labeled human $\mathrm{C}^{\prime} 3$ has been documented both by direct hemolytic activity measurements as well as by uptake determinations with $\mathrm{EAC}^{\prime} 1$,4,2a (4).

Alper, Levin, and Rosen (5) and Alper and Rosen (6) investigated the metabolic behavior of $C^{\prime} 3$ in normal subjects and reported abnormalities of metabolism in some patients with renal diseases and systemic lupus erythematosus. These authors found no important abnormalities of metabolism in patients with acquired hemolytic anemia, paroxysmal nocturnal hemoglobinuria, hereditary angioneurotic edema, or rheumatoid arthritis.

This paper reports a study of the in vivo metabolism of purified $C^{\prime} 3$ labeled with ${ }^{125}$-iodine $\left(C^{\prime} 3\right.$ ${ }^{125} \mathrm{I}$ ) in normal subjects and in patients with acquired hemolytic anemias. 27 such studies were performed; in addition, three studies were performed using $C^{\prime} 3 \mathrm{i}$, the biologically inactive reaction product of $\mathrm{C}^{\prime} 3$ that was prepared by in vitro reaction of $C^{\prime} 3$ with the $\left(C^{\prime} 4 i, 2\right)$ a complex. ${ }^{1}$ The

1 The complement nomenclature used in this publication conforms with the recommendations of the active members of the Complement Workshops held in Bethesda, Md., 1963 (7), and in La Jolla, Calif., 1966 (8). Individual complement components are designated numerically.

To convey the results of recent studies, the following additional symbols and terms will be used in the present publication. They are constructed in accordance with the general rules for complement nomenclature: $\mathrm{C}^{\prime} 3$; the third component of complement, previously referred to as $\beta_{1 \mathrm{c}}$-globulin. $\mathrm{F}(\mathrm{a}) \mathrm{C}^{\prime} 3, \mathrm{~F}(\mathrm{~b}) \mathrm{C}^{\prime} 3, \mathrm{~F}(\mathrm{c}) \mathrm{C}^{\prime} 3, \mathrm{~F}(\mathrm{~d}) \mathrm{C}^{\prime} 3$; four fragments that result from enzymatic cleavage of $C^{\prime} 3$ (2). F(a) and $F(b)$ are produced by cleavage of $C^{\prime} 3$ by $C^{\prime} 3$ convertase $\left(C^{\prime} 4,2 a\right)$. This enzyme has been shown (2) to cleave $C^{\prime} 3$ only into $F(a)$ and $F(b) C^{\prime} 3$. findings are in good agreement with those of Alper and Rosen (6) concerning the metabolic behavior of $C^{\prime} 3$ in normal subjects and document significant abnormalities in patients with acquired hemolytic anemias.

\section{METHODS}

\section{A. Subjects}

Normal control subjects consisted of hospital personnel in apparently excellent health who were hematologically normal, had negative direct Coombs tests, normal levels of $C^{\prime} 3$, and normal levels of serum complement. At least one normal control was studied with each preparation of labeled protein, except in one study which included instead a hematologically normal patient hospitalized for peptic ulcer. This patient had elevated levels of $\mathrm{C}^{\prime} 3$ and serum complement. Patients with hemolytic anemia were classified according to Dacie's nomenclature (11) and had the following diagnoses: idiopathic autoimmune hemolytic anemia (AIHA) of warm and cold antibody types, secondary AIHA of warm antibody type associated with lymphoma and lupoid hepatitis (chronic active hepatitis), Coombs positive hemolytic anemia associated with $\alpha$-methyldopa administration, and paroxysmal nocturnal hemoglobinuria (PNH).

All patients diagnosed as AIHA had a positive direct Coombs test using a broad spectrum antiglobulin reagent. The direct Coombs test was also performed using monospecific antisera against IgG, $C^{\prime} 3$, and $C^{\prime} 4$. The AIHA patients studied included those whose erythrocytes were coated with IgG only, IgG and complement components, and complement components only.

\section{B. Immunologic and special hematologic techniques}

1. Serum complement $\left(C^{\prime}\right)$. Serum complement was determined by a modification of the sensitized sheep cell assay as described by Kabat and Mayer (12). The results were expressed in terms of $50 \%$ hemolytic units $/ \mathrm{ml}$ $\left(\mathrm{C}^{\prime} \mathrm{H}_{\mathrm{so}} \mathrm{u} / \mathrm{ml}\right)$.

2. Serum $C^{\prime} 3$ determination. The concentration of $C^{\prime} 3$ in serum was determined by the radial immunodiffusion technique of Mancini, Carbonara, and Heremans (13). Antiserum to $C^{\prime} 3$ was prepared as previously described

At neutral $\mathrm{pH}$ the two fragments tend to remain in loose association and it is this material that is called $C^{\prime} 3 \mathrm{i}$. $F(c)$ and $F(d)$ result from secondary proteolytic degradation of $F(b) C^{\prime} 3$ (9). In whole serum, $C^{\prime} 3 i$ undergoes degradation (2) and the resulting products have been called $B_{1 \mathrm{~A}}$-globulin and $\alpha_{2 \mathrm{D}}$-globulin (10). $\mathrm{C}^{\prime} 4 \mathrm{i} ; \mathrm{C}^{\prime} 1$ esterase-treated $\mathrm{C}^{\prime} 4$ that has undergone characteristic physiocochemical changes and has lost the capacity to become bound to groups that serve as $C^{\prime} 4$ receptors. $\left(C^{\prime} 4 i, 2\right) a$; protein-protein complex, derived from $C^{\prime} 2$ and $C^{\prime} 4$ by the action of $\mathrm{C}^{\prime} 1$ esterase in the presence of $\mathrm{Mg}^{++}$; possessing capacity to convert $C^{\prime} 3$ to $C^{\prime} 3 i\left[F(a)+F(b) C^{\prime} 3\right]$. 
(14). Standard solutions of known concentrations were prepared with the purified $C^{\prime} 3$ protein (15). The protein concentration was determined by the Folin-Ciocalteu method (16) with a previously calibrated standard curve that was based on nitrogen measurements by the Kjeldahl method (17). Five dilutions of a known standard solution were used in duplicate on each plate and all $C^{\prime} 3$ concentrations of test sera fell within the range of these standards. The concentrations of the standards were plotted on arithmetic paper against the diameter of the precipitation rings.

All determinations were carried out in duplicate on each plate, and were done on each individual on three different dates during the study. The standard error of the method was $10 \%$.

3. Serologic studies. A detailed serologic evaluation of each of the patients with Coombs positive hemolytic anemia was carried out by standard serologic techniques (18). Monospecific antiglobulin sera to $C^{\prime} 3, C^{\prime} 4$, and IgG were prepared as previously described $(14,19,20)$. The titer of warm autoantibodies against pooled type $O$ erythrocytes was determined at $37^{\circ} \mathrm{C}$ by saline agglutination and indirect Coombs test with untreated erythrocytes, and by saline agglutination with trypsinized erythrocytes. Eluates were made by heat elution (21), or by ether elution (22). Serum and eluates were tested for $\mathrm{Rh}$ specificity of the autoantibody with enzyme-treated erythrocytes by titering against at least three samples of type $O$ erythrocytes with $R h$ genotypes $r r, R^{1} R^{1}$, and $R^{2} R^{2}$. High-titered cold agglutinins were tested for $I i$ blood group specificity by titering against pooled type $\mathrm{O}$ erythrocytes from normal adults and against cord cells.

Screening tests for in vitro hemolytic capability of the autoantibodies were carried out at 23 and $37^{\circ} \mathrm{C}$ against pooled normal and enzyme-treated erythrocytes. The patients' sera were diluted in equal volumes of fresh normal serum to assure the presence of adequate amounts of complement. Hemolysis screening tests were also carried out with acidified serum ( $\mathrm{pH} 6.5-7.0$ ) and, when positive, hemolysis titrations were carried out using those conditions giving maximal lysis in screening tests.

A Donath-Landsteiner test was carried out on each patient using the patient's serum diluted with equal volumes of fresh normal serum to insure the presence of adequate amounts of complement (18).

4. Additional techniques. Immune adherence was performed as described by Nelson (23). Freshly obtained complement-sensitized erythrocytes from patients, or stroma made from such cells, were tested as antigenantibody- $C^{\prime}$ complexes using group $\mathrm{O}, \mathrm{Rh}$ negative human erythrocytes as indicator particles. Positive controls included erythrocytes and stroma sensitized with complement fixing isoantibodies.

Serum haptoglobin was determined by the method of Owen, Better, and Hoban (24). The Ham's test and urine hemosiderin were performed as described by Dacie and Lewis (18), the sugar-water test as described by Hartmann and Jenkins (25).

Immunoelectrophoresis was performed as described by Heremans (26) in a cold room, using $1.5 \%$ Noble agar in $\mathrm{pH} 8.6$ barbital buffer with EDTA added to a concentration of 0.005 mole/liter. All plasma specimens contained EDTA added to a concentration of $0.01 \mathrm{~mole} /$ liter.

\section{Radioisotope studies}

1. Preparation of ${ }^{125} I$-labeled $C^{\prime} 3$ and $C^{\prime} 3 i$. Purified $C^{\prime} 3$ was prepared and labeled with ${ }^{125} \mathrm{I}$ as described previously $(4,15)$.

$500 \mu \mathrm{c}$ of ${ }^{125} \mathrm{I}$ was added in carrier-free form without preservatives or reducing substances to $2 \mathrm{mg}$ of protein in $4 \mathrm{ml}$ ice cold veronal-sodium chloride buffer, $\mathrm{pH} 7.3$. While the protein-iodine mixture was stirred, $100 \mu \mathrm{g}$ of chloramine- $\mathrm{T}(200 \mu \mathrm{g} / \mathrm{ml}$ of solution in distilled water) was added and allowed to react for $5 \mathrm{~min}$. The oxidizing agent was then neutralized by the addition of $100 \mu \mathrm{g}$ of sodium meta bisulfite. To remove unbound iodine, the iodinated protein was dialyzed for $24 \mathrm{hr}$ against $3 \times 10$ liters of veronal-sodium chloride buffer. Iodine uptake varied between 50 and $80 \%$, and the specific radioactivity of labeled $\mathrm{C}^{\prime} 3$ between $3 \times 10^{4}$ and $7 \times 10^{4} \mathrm{cpm} / \mu \mathrm{g}$. Immediately after labeling, human serum albumin was added to the preparation to a concentration of $0.2 \%$. All preparations were kept in the cold during the 48-hr interval between isolation and administration of the protein. When an aliquot of the labeled C'3 was passed through a Sephadex G-200 column, $96 \%$ of the radioactivity was found to be protein-bound.

The nonpyrogenicity of $C^{\prime} 3$ was secured by the fact that the isolation of $C^{\prime} 3$ was carried out in the presence of antibiotics with autoclaved buffers and there was frequent filtration of the partially purified material to remove bacterial contamination. The final product was passed twice through a bacterial filter and chloramphenicol was added to a concentration of $5 \times 10^{-5}$ moles/liter. Frequent pyrogenicity tests were carried out with the purified preparations in rabbits according to standard procedures. No significant untoward reactions were noted during the study.

Radioiodinated $C^{\prime} 3 \mathrm{i}$ was prepared by reacting ${ }^{120} \mathrm{I}$-labeled $C^{\prime} 3$ with $\left(C^{\prime} 4 i, 2\right)$ a $(27)$. Immunoelectrophoresis revealed complete conversion of $C^{\prime} 3$ to $C^{\prime} 3 i$; the antiserum used in immunoelectrophoresis had specificity for $F(b), F(c)$, and $F(d) C^{\prime} 3$ (2) but no reaction products other than $\mathrm{C}^{\prime} 3 \mathrm{i}$ were detected.

Studies with $C^{\prime} 3 i$ were performed on two normal persons and one patient with idiopathic AIHA (patient A. F.) with a single batch of labeled $\mathrm{C}^{\prime} 3 \mathrm{i}$.

2. Administration of labeled proteins and collections of samples. One normal subject was studied simultaneously with several patients (usually three) with hemolytic anemia. The subjects were given Lugol's solution before and during the entire study to prevent thyroidal uptake of the administered ${ }^{120} \mathrm{I}$. Approximately $0.75 \mathrm{ml}$ of the iodinated preparation, containing from 0.5 to $1 \mathrm{mg}$ of $\mathrm{la}$ beled protein and 15-60 $\mu \mathrm{c}$ of radioactivity, was injected intravenously from a disposable tuberculin syringe. The exact amount of radioactive solution administered was determined by weighing the syringe before and after the 
injection. Blood samples of 14-ml in EDTA anticoagulant were obtained at $15 \mathrm{~min}, 2,4$, and $6 \mathrm{hr}$, three times during the next $24 \mathrm{hr}$, and twice daily thereafter for 5 days. Samples were treated after a delay of no longer than several hr. Two aliquots of plasma of 2-ml each were pipetted into tubes and the proteins in one aliquot were precipitated and washed twice in $10 \%$ trichloroacetic acid (TCA) and made up to a volume of $2 \mathrm{ml}$.

The erythrocytes from the entire sample were washed three times in saline, were then centrifuged, and saline was added to the packed erythrocytes to a volume of 5 $\mathrm{ml}$. A hematocrit was done on the erythrocyte suspension and in some experiments the erythrocytes were lysed with a pinch of saponin before counting.

Urine was collected from all subjects in 12-hr aliquots. The total volume of urine was measured and $5-\mathrm{ml}$ specimens were counted. TCA was added to aliquots of the urine, but in no case was significant TCA precipitable protein-bound radioactivity detected. Excretion of ${ }^{105} \mathrm{I}$ in the stool was not measured, but has been reported to be negligible after catabolism of $C^{\prime} 3$ (6).
Standards were prepared in $2 \%$ bovine serum albumin by making a 1:4000 dilution in triplicate of the ${ }^{120} \mathrm{I}$-labeled $C^{\prime} 3$. Three aliquots of both $2-$ and $5-\mathrm{ml}$ volumes were prepared for counting with specimens of similar volume. The proteins in an additional set of $2-\mathrm{ml}$ standards made up in normal serum were precipitated and washed twice with $10 \%$ TCA. All samples from a single study were analyzed simultaneously for radioactivity in a Packard gamma scintillation counter at the end of the study period to eliminate the need to correct for isotope decay.

After completion of each study, a plasma volume was determined in 23 subjects using commercially prepared ${ }^{105}$ I-labeled albumin. ${ }^{2}$

3. Analysis of data. The data were plotted on semilogarithmic paper against time. The values for plasma or TCA precipitated proteins were expressed as percentage of the radioactivity in the $15 \mathrm{~min}$ specimen. The values declined in a straight line after the initial equili-

2 Albumotope, E. R. Squibb \& Sons, New York.

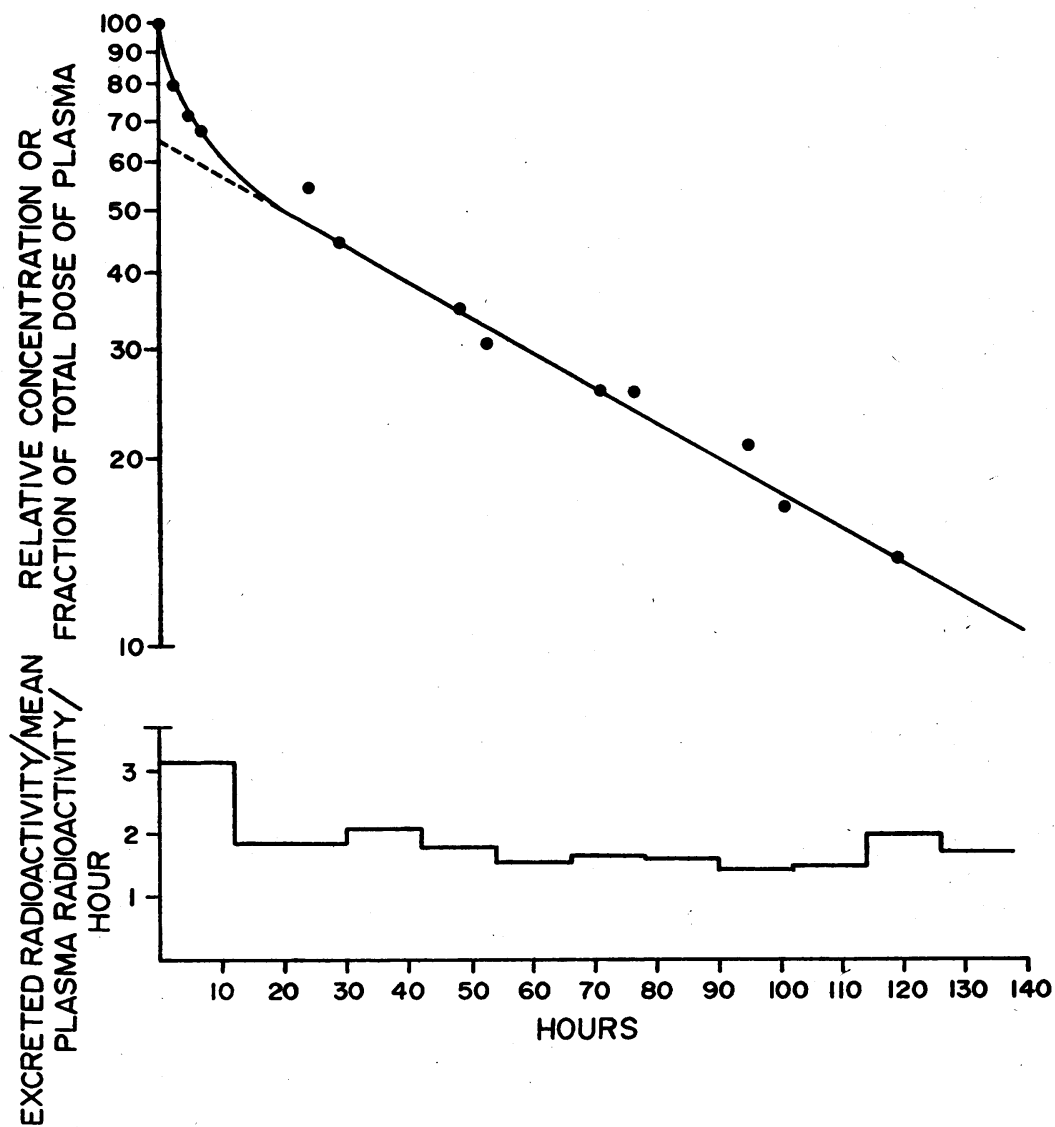

FIgURE 1 The top portion of the figure shows the plasma disappearance of $C^{\prime} 3-{ }^{150} I$ and the lower portion shows the ratios of urinary excretion of the label per unit time to the mean plasma radioactivity during that period of time (Patient F. M.). The fact that such plots of " $u / p$ " ratios are horizontal indicates homogeneity of the protein, and that synthesis and catabolism occur in or in close connection with the plasma pool. 
bration period and the plasma disappearance half-life of $C^{\prime} 3$ was estimated by graphic means from the final slope. The initial slope was determined in the usual manner by projecting the final slope back to time zero and then subtracting values on this line from those of corresponding times on the initial part of the plasma disappearance curve.

Further analysis of the data was carried out according to the method of Nosslin (28-30). With this mathematical model based on analysis of the initial and final slopes and their intercepts, one may calculate the fractional catabolic rate of $C^{\prime} 3$, the size of intravascular and extravascular compartmental pools, and the rate of synthesis of C'3. Nosslin's method of analysis requires that the labeled protein is metabolically homogeneous, that subjects are in a steady state, and that synthesis and catabolism occur in or in close connection with the plasma pool. No assumptions are made concerning the number and arrangements of the extravascular pools.

Each batch of isolated protein used was homogeneous according to the criteria of disc-polyacrylamide gel electrophoresis (31) and immunoelectrophoresis against antiwhole human serum. Immunoelectrophoresis of an aliquot of injected material was performed in order to ascertain whether the protein was present in the electrophoretically slower, hemolytically active form of $\mathrm{C}^{\prime} 3$ rather than in the electrophoretically faster and inactive form, $C^{\prime} 3 i$ (4).

The patients were in a steady state during the 5 days of the study, as indicated by stable weight, hematocrit, reticulocyte count, and serum $\mathrm{C}^{\prime} 3$ concentration determined on three dates during the study. That synthesis and catabolism occur in or in close connection with the plasma pool was tested by plotting the ratio of the urinary excretion per unit time to the mean plasma radio-

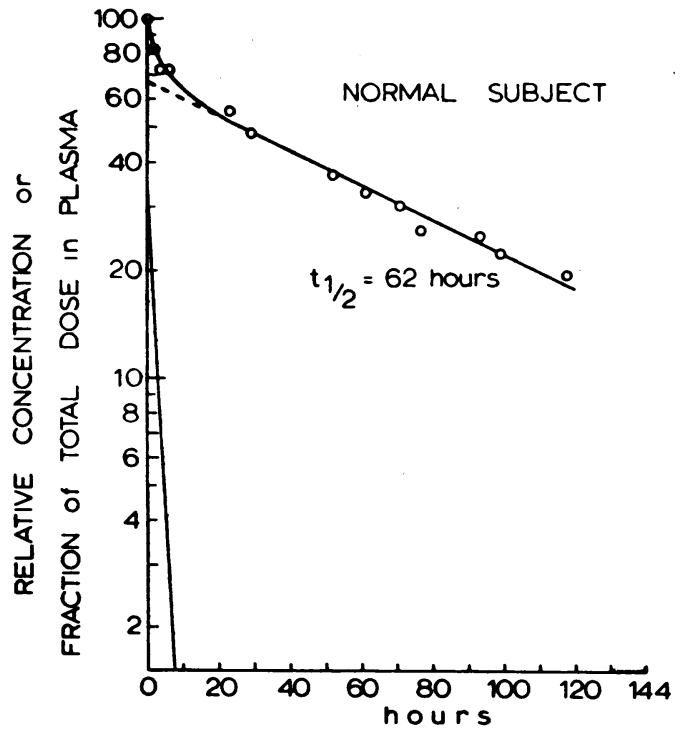

activity during that period of time (28). Such plots were, in general, horizontal after the initial equilibration period and a representative plot is shown in Fig. 1. It may be added that a degradation has been shown to take place in a compartment in rapid equilibrium with the plasma space "in all experimental cases so far studied" with a large variety of plasma proteins (28).

The initial distribution space for $\mathrm{C}^{\prime} 3$ was calculated in most studies from the radioactivity in a specimen of plasma obtained $15 \mathrm{~min}$ after injection of the labeled protein. The initial distribution space thus calculated was compared with the plasma volume measured with ${ }^{125}$ I-labeled albumin after completion of the study in 23 subjects. In 16 patients injected with $C^{\prime} 3$, these values agreed to within $9 \%$ on an average, and there were no systematic differences. When both determinations were available, the mean of these two values was recorded as the plasma volume and was used in calculation of the plasma pool size and $C^{\prime} 3$ synthesis rates. Using one preparation of $C^{\prime} 3$ that was heterogeneous and the $C^{\prime} 3 i$ preparation, there were large discrepancies between the two values (see below).

\section{RESULTS}

The clinical data, serum $C^{\prime}$ levels, serum $C^{\prime} 3$, direct Coombs tests, and the radioisotope data of all subjects are summarized in Tables I-III. Direct Coombs tests titers of patients with hemolytic anemia done with monospecific antisera to IgG, $C^{\prime} 3$, and $C^{\prime} 4$ are given in Table IV. Hematologic and serologic data of patients with hemolytic anemia are given in Table V. The $\mathrm{C}^{\prime}{ }^{3-{ }^{125} \mathrm{I}}$ plasma disappearance curves of a typical normal subject

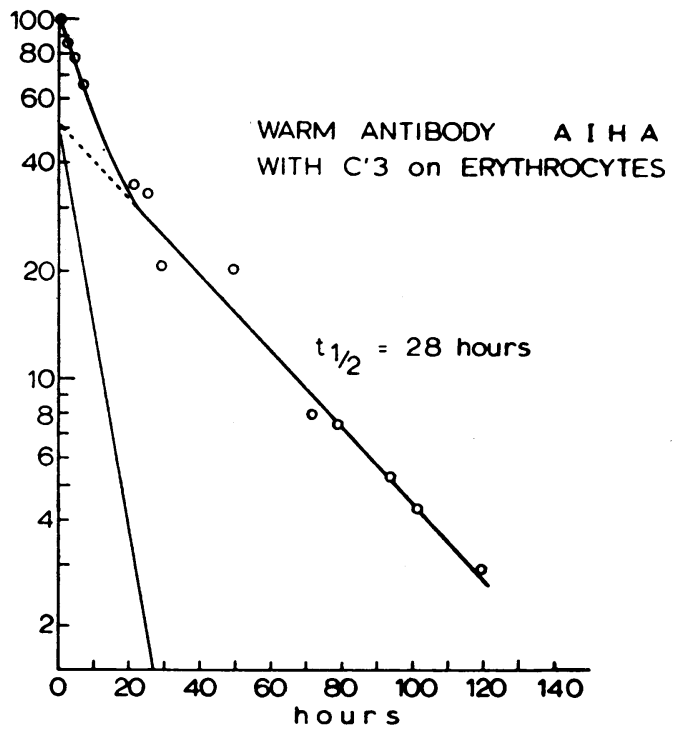

FIGURE 2 The $C^{\prime}{ }^{-185}$ I plasma disappearance curve of normal control F. W. and patient A. F. 
TABLE I

Summary oj Data Concerning Normal Subjects

\begin{tabular}{|c|c|c|c|c|c|c|c|c|c|c|c|}
\hline Subject & Age & Wt & Sex & $\begin{array}{c}\text { Total } \\
\text { serum } \\
\text { complement }\end{array}$ & $\begin{array}{l}\text { Plasma } \\
\text { disappear- } \\
\text { ance half- } \\
\text { t life of } C^{\prime} 3\end{array}$ & $\begin{array}{c}\text { Serum } \\
C^{\prime} 3\end{array}$ & $\begin{array}{l}\text { Plasma } \\
\text { volume }\end{array}$ & $\begin{array}{c}\text { Total } \\
\text { intra- } \\
\text { vascular } \\
\text { C'3 }^{\prime} 3 \text { pool }\end{array}$ & $\begin{array}{l}\text { Intra- } \\
\text { vascular } \\
\text { distribu- } \\
\text { tion }\end{array}$ & $\begin{array}{l}\text { Fractional } \\
\text { catabolic } \\
\text { rate }\end{array}$ & $\begin{array}{c}\mathrm{C}^{\prime} 3 \\
\text { synthesis } \\
\text { rate }\end{array}$ \\
\hline & $y r$ & kg & & $\begin{array}{c}\mathrm{C}^{\prime} \mathrm{H}_{50} \\
\text { units } / m l\end{array}$ & $h r$ & $m g / m l$ & $m l$ & $m g$ & $\begin{array}{c}\% \text { of total } \\
\text { pool }\end{array}$ & $\% / h r$ & $\mathrm{mg} / \mathrm{kg}$ per $\mathrm{hr}$ \\
\hline C. H. & 30 & 84 & $\mathbf{M}$ & 150 & 47 & 1.39 & 3120 & 4337 & 72 & 2.10 & 1.08 \\
\hline C. K. & 29 & 66.4 & M & 143 & 41 & 1.15 & 3030 & 3480 & 86 & 1.97 & 1.03 \\
\hline V. M. & 34 & 76 & $\mathbf{M}$ & 151 & 47 & 1.35 & 2888 & 3899 & 68 & 2.19 & 1.12 \\
\hline B. C. & 24 & 84.1 & $\mathbf{M}$ & 148 & 48 & 1.63 & 3149 & 5133 & & & \\
\hline K. S. & 29 & 78.2 & $\mathbf{M}$ & 146 & 48 & 1.32 & 3712 & 4900 & 73 & 2.10 & 1.31 \\
\hline F. W. & 26 & 79.5 & $\mathbf{M}$ & 102 & 62 & 1.45 & 3335 & 4836 & 68 & 1.74 & 1.06 \\
\hline M. E. & 41 & 72.7 & $\mathbf{M}$ & 130 & 49 & 1.31 & 3063 & 4013 & 66 & 2.37 & 1.31 \\
\hline R. E. & 25 & 72.7 & $\mathbf{M}$ & 110 & 50 & 1.23 & 3782 & 4652 & 69 & 2.17 & 1.39 \\
\hline J. C. & 31 & 78.2 & $\mathbf{M}$ & 93 & 48 & 1.00 & 3100 & 3100 & 56 & 2.71 & 1.07 \\
\hline T. H. & 32 & 68.2 & $\mathbf{M}$ & 113 & 53 & 1.50 & 2902 & 4377 & 66 & 2.00 & 1.28 \\
\hline W. S. & 26 & 84.1 & $\mathbf{M}$ & 125 & 48 & 1.22 & 3641 & 4442 & 64 & 2.30 & 1.22 \\
\hline D. R. & 40 & 62.8 & $\mathrm{~F}$ & 115 & 82 & 1.54 & 2508 & 3862 & 54 & 1.64 & 1.01 \\
\hline R. T. & 31 & 57.3 & $\mathbf{M}$ & 110 & 63 & 1.33 & 2235 & 2972 & 57 & 2.15 & 1.10 \\
\hline
\end{tabular}

(F. W.) and a patient with warm antibody idiopathic AIHA with complement sensitization of her erythrocytes (A. F.) are illustrated in Fig. 2.

Normal subjects (Table I). The mean whole serum $\mathrm{C}^{\prime}$ level in 23 normal hospital personnel was $138 \mathrm{C}^{\prime} \mathrm{H}_{50}$ units/ml and the normal range (defined throughout as 2 SD above and below the mean) was from 96 to 180 . These normal values are higher than often reported because of the lower concentration of erythrocytes in our modification of the sensitized sheep cell assay.

The mean serum concentration of $\mathrm{C}^{\prime} 3$ in 22 normal hospital personnel was $1.43 \mathrm{mg} / \mathrm{ml}$ with a normal range of from 1.00 to 1.87 . These values agree well with previously published data (1).

The normal range for the fractional catabolic rate of $\mathrm{C}^{\prime} 3$ was from 1.56 to $2.68 \% / \mathrm{hr}$ with a mean of 2.12. The normal range for the percentage of $\mathrm{C}^{\prime} 3$

TABLE II

Summary of Data on Patients with Warm Antibody Auto-

\begin{tabular}{|c|c|c|c|c|c|c|c|}
\hline \multirow[b]{2}{*}{ Subject } & \multirow[b]{2}{*}{ Diagnosis } & \multirow[b]{2}{*}{ Age } & \multirow[b]{2}{*}{$W_{t}$} & \multirow[b]{2}{*}{ Sex } & \multicolumn{3}{|c|}{ Direct Coombs test* } \\
\hline & & & & & Anti-IgG & Anti $C^{\prime} 3$ & Anti $C^{\prime} 4$ \\
\hline & & $y r$ & $k g$ & & & & \\
\hline H. H. & $\begin{array}{l}\text { Idiopathic warm antibody } \\
\text { AIHA }\end{array}$ & 44 & 65 & $\mathrm{~F}$ & Strong & Strong & Weak \\
\hline H. H. & $"$ & 44 & 64.9 & $\mathrm{~F}$ & Strong & Strong & Weak \\
\hline A. F. & " & 40 & 61.7 & $\mathrm{~F}$ & Strong & Strong & Strong \\
\hline A. F. & $"$ & 40 & 59.5 & $\mathrm{~F}$ & Strong & Strong & Strong \\
\hline E. B. & " & 68 & 68.1 & $\mathrm{~F}$ & Negative & Moderate & Moderate \\
\hline J. T. & $\begin{array}{l}\text { Warm antibody AIHA- } \\
\text { chronic active hepatitis }\end{array}$ & 18 & 64.0 & $\mathrm{~F}$ & Weak & Strong & Strong \\
\hline M. M. & $\begin{array}{l}\text { Warm antibody AIHA- } \\
\text { lymphoma }\end{array}$ & 53 & 62.3 & M & Moderate & Weak & Moderate \\
\hline M. D. & $\begin{array}{l}\text { Idiopathic warm antibody } \\
\text { AIHA }\end{array}$ & 88 & 66.1 & M & Weak & Weak & Weak \\
\hline
\end{tabular}

* Detailed results of direct Coombs test titrations are given in Table IV. 
that was intravascular was from 51 to $83 \%$ with a mean of 67 . The $\mathrm{C}^{\prime} 3$ synthesis rate averaged 1.16 $\mathrm{mg} / \mathrm{kg}$ per hr with a normal range of from 0.90 to 1.42 .

Warm antibody AIHA with $C^{\prime} 3$ sensitization of erythrocytes (Table II). Eight radioisotope studies were done on six patients with warm antibody AIHA with complement components on their erythrocytes. As shown in Fig. 3, the fractional catabolic rate was at upper limit of normal or was above normal in all 5 patients for which this value was calculated. The $C^{\prime} 3$ synthesis rate was just above the upper limit of normal in patients M. M. and M. D., was moderately increased in patients H. H. and J. T., and distinctly increased in patient A. F. The percentage of protein that was intravascular was within the normal range, except for patient $\mathrm{H}$. $\mathrm{H}$. in whom the percentage was low.

There was usually an association between serum complement and serum $C^{\prime} 3$ levels, as indicated by patients H. H., J. T., and M. D. in whom these values were both low, and patient $\mathrm{E}$. B. in whom they were both normal. However, in patient A. F., serum complement was consistently low in spite of $\mathrm{C}^{\prime} 3$ values within the normal range. Conversely, the serum $\mathrm{C}^{\prime} 3$ level of patient M. M. was about $20 \%$ below the lower limit of normal, but his total serum $C^{\prime}$ was within normal limits.

In one study concerning four subjects (patients

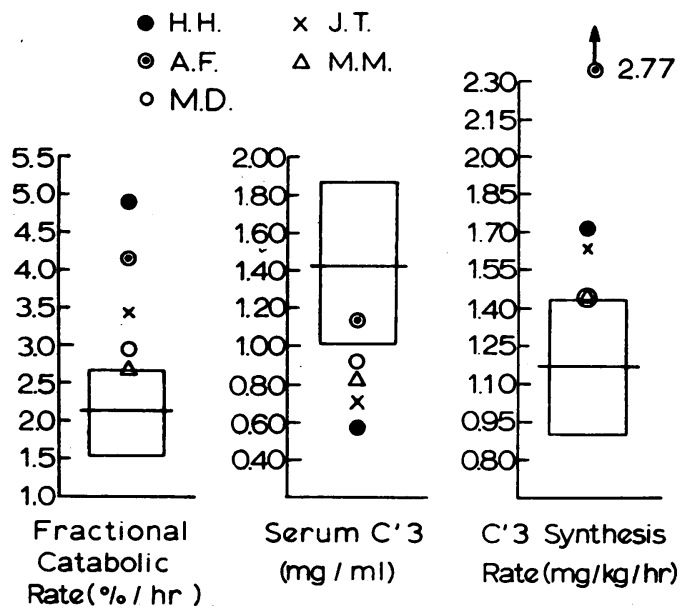

Figure 3 Summary of data on patients with warm antibody AIHA who had $C^{\prime} 3$ on their erythrozytes.

H. H., A. F., and E. B., and normal subject B. C.) there was partial denaturation of $C^{\prime} 3$ or partial conversion to $\mathrm{C}^{\prime} 3 \mathrm{i}$ during isolation and labeling. Rapid removal of a portion of the $\mathrm{C}^{\prime} 3{ }^{-125} \mathrm{I}$ from the plasma was indicated by the fact that the initial distribution spaces of $\mathrm{C}^{\prime} 3{ }^{125} \mathrm{I}$ calculated from the $15 \mathrm{~min}$ specimens for subjects $H$. H., A. F., E. B., and B. C. were, respectively, 65,57 , 71 , and $47 \%$ above the true plasma volumes measured with ${ }^{125} \mathrm{I}$-albumin. The urinary excretion of radioactivity was high during the 1 st $24 \mathrm{hr}$, averaging $65 \%$ of the injected dose. These findings

immune Hemolytic Anemia with $C^{\prime} 3$ on Their Erythrocytes

\begin{tabular}{|c|c|c|c|c|c|c|c|}
\hline $\begin{array}{c}\text { Total } \\
\text { serum } \\
\text { complement }\end{array}$ & $\begin{array}{c}\text { Plasma } \\
\text { disappearance } \\
\text { half-life of } C^{\prime} 3\end{array}$ & $\underset{C^{\prime} 3}{\text { Serum }}$ & $\begin{array}{l}\text { Plasma } \\
\text { volume }\end{array}$ & $\begin{array}{c}\text { Total } \\
\text { Intravascular } \\
C^{\prime} 3 \text { pool }\end{array}$ & $\begin{array}{l}\text { Intravascular } \\
\text { distribution }\end{array}$ & $\begin{array}{c}\text { Fractional } \\
\text { catabolic rate }\end{array}$ & $\begin{array}{l}C^{\prime} 3 \text { synthesis } \\
\text { rate }\end{array}$ \\
\hline $\mathrm{C}^{\prime} \mathrm{H}_{\text {sounits } / m l}$ & $h r$ & $m g / m l$ & $m l$ & $m g$ & $\begin{array}{c}\% \text { of total } \\
\text { pool }\end{array}$ & $\% / h r$ & $m g / k g$ per $h r$ \\
\hline 64 & 32 & 0.58 & 3676 & 2132 & & & \\
\hline 54 & 38 & 0.58 & 3942 & 2287 & 43 & 4.87 & 1.72 \\
\hline 72 & 26 & 1.18 & 2716 & 3205 & & & \\
\hline 51 & 28 & 1.13 & 3522 & 3980 & 68 & 4.14 & 2.77 \\
\hline 138 & 27 & 1.24 & 2206 & 2735 & & & \\
\hline 66 & 28 & 0.71 & 4222 & 2998 & 79 & 3.46 & 1.62 \\
\hline 118 & 41 & 0.83 & 3969 & 3294 & 70 & 2.70 & 1.43 \\
\hline 94 & 45 & 0.92 & 3500 & 3220 & 57 & 2.93 & 1.43 \\
\hline
\end{tabular}



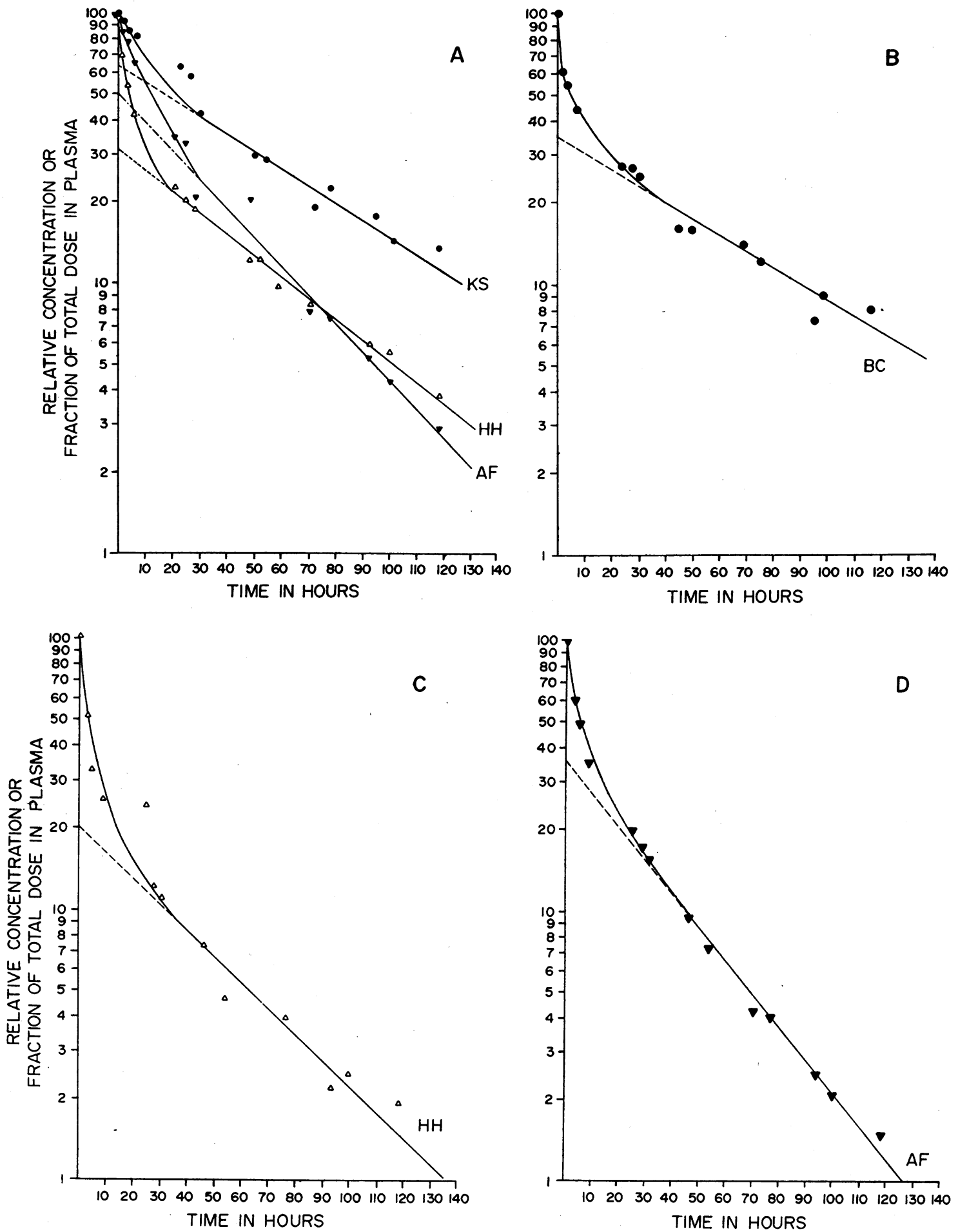

FIGURE 4 Plasma disappearance of $C^{\prime} 3-{ }^{125} \mathrm{I}$ with a homogeneous protein preparation (A) and a preparation that was partially denatured or converted to $\mathrm{C}^{\prime} 3 \mathrm{i}(\mathrm{B}, \mathrm{C}, \mathrm{D})$. A. F. and $\mathrm{H}$. H. are patients with warm antibody AIHA with complement on their erythrocytes; and K. S. and B. C. are normal subjects. The data are plotted as the percentage of radioactivity in the $15 \mathrm{~min}$ specimen. Rapid removal of denatured $\mathrm{C}^{\prime} 3-^{125} \mathrm{I}$ in the study illustrated in $\mathrm{B}, \mathrm{C}$, and $\mathrm{D}$ was indicated by the erroneously high plasma volumes calculated with $\mathrm{C}^{\prime} 3-^{125} \mathrm{I}$ 
indicated that the protein was not homogeneous and therefore made it impossible to interpret the data according to Nosslin's mathematical model or any other current mathematical approach (29). The radioisotope study was repeated in two patients (H. H. and A. F.), again simultaneously with a normal control (K. S.), and there was good agreement between the $\mathrm{C}^{\prime} 3-{ }^{125} \mathrm{I}$ initial distribution space and the plasma volume measured with ${ }^{125} \mathrm{I}$ albumin in all three subjects. The final slope of the plasma disappearance curve was similar to the earlier study in both patients (Fig. 4; Table II). This indicates that a portion of the protein in the earlier study was catabolized rapidly while the remainder functioned normally thereafter.

Other patients (Table III). The data concerning patients with hemolytic anemias other than warm antibody AIHA with complement sensitization of erythrocytes, and a patient with a healing peptic ulcer are listed in Table III and some of the pertinent information is summarized in Fig. 5.

One patient with hemolytic anemia associated with $\alpha$-methyldopa administration had erythrocytes strongly sensitized with IgG but had no complement on her erythrocytes. The values for serum $\mathrm{C}^{\prime}$ and $\mathrm{C}^{\prime} 3$, plasma disappearance half-life of $\mathrm{C}^{\prime} 3$, ratio of intravascular to extravascular pools, fractional catabolic rate, and rate of synthesis of $\mathrm{C}^{\prime} 3$ were normal.

Two patients with $\mathrm{PNH}$ were studied (D. L. and D. M.). Patient D. L. was studied twice, first at a time when he was asymptomatic, and subsequently while he had moderately severe abdominal pain and persistent hemoglobinuria. Measurements of complement metabolism were normal in patient $\mathrm{D}$. L., when he was asymptomatic, but during the hemoglobinuric episode the $\mathrm{C}^{\prime} 3$ fractional catabolic rate was elevated, as was the $C^{\prime} 3$ synthesis rate. The single study on patient D. M. (performed during chronic hemolysis) also revealed an increased fractional catabolic rate and distinctly elevated $C^{\prime} 3$ synthesis rate.
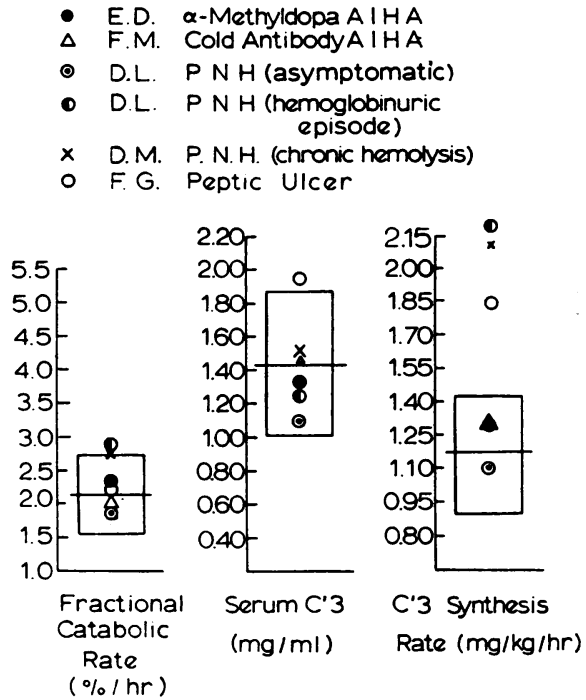

FIGURE 5 Summary of data on patients with miscellaneous diagnoses.

One patient (F. M.) had a hemolytic anemia associated with a cold agglutinin titer of $1: 1000$. At the time of the radioisotope study this patient was in partial remission. Although her direct Coombs test remained positive, her serum complement and serum $\mathrm{C}^{\prime} 3$ were normal, as were her plasma disappearance half-life of $C^{\prime} 3$, extravascular/intravascular pool ratios, and synthesis rate of $\mathrm{C}^{\prime} 3$.

A hematologically normal subject with a healing peptic ulcer (F. G.) had elevated levels of serum complement and $C^{\prime} 3$, had normal values for plasma disappearance half-life of $\mathrm{C}^{\prime} 3$, fractional catabolic rate, ratio of extravascular to intravascular pools, and had an increased synthesis rate of C'3.

Isotope studies with $C^{\prime} 3 i$. The three studies done with $\mathrm{C}^{\prime} 3 \mathrm{i}-{ }^{125} \mathrm{I}$ revealed very rapid removal of the labeled protein from the plasma. The first sample, withdrawn after 15 min showed only an average of $47 \%$ of the injected protein remaining in the plasma and after $2 \mathrm{hr}$ only $10 \%$ or less re-

(see text). An excessive rate of plasma disappearancc continued to occur until the plasma disappearance curve reached its final slope. It is illustrated here by the fact that when the final slope is projected back to time zero, it intercepts the ordinate at the abnormally low value of 35 in normal subject B. C. (B). (The mean value for the intercept in normals was 58 , the mean \pm 2 SD was $43-73$, and the lowest measured value in other normal subjects was 46.) This intercept is also significantly lower in the patients in $C$ and $D$ than when a homogeneous protein was used (A). This continued rapid plasma disappearance of $\mathrm{C}^{\prime} 3{ }^{125} \mathrm{I}$ during the 1 st day, which is due to the heterogeneity of the protein, would result in erroneously high values for fractional catabolic rate, $C^{\prime} 3$ synthesis rate, and the ratio of extravascular/intravascular pool sizes. Similar data were obtained for subject E. B., but are not included here since a repeat study was not performed. 
TABLE III

Summary of Data on Patients

\begin{tabular}{|c|c|c|c|c|c|c|c|}
\hline \multirow[b]{2}{*}{ Subject } & \multirow[b]{2}{*}{ Diagnosis } & \multirow[b]{2}{*}{ Age } & \multirow[b]{2}{*}{$\mathrm{Wt}_{\mathrm{t}}$} & \multirow[b]{2}{*}{ Sex } & \multicolumn{3}{|c|}{ Direct Coombs test* } \\
\hline & & & & & Anti-IgG & Anti-C'3 & Anti-C $\mathbf{C}^{\prime} \mathbf{4}$ \\
\hline & & $y r$ & $\mathrm{~kg}$ & & & & \\
\hline E. D. & $\begin{array}{l}\alpha \text {-methyldopa-induced } \\
\text { warm antibody } \\
\text { AIHA }\end{array}$ & 62 & 60.2 & $\mathrm{~F}$ & Strong & Negative & Negative \\
\hline F. M. & $\begin{array}{l}\text { Atypical cold antibody } \\
\text { AlHA }\end{array}$ & 65 & 65.2 & $\mathbf{F}$ & Negative & Strong & Strong \\
\hline D. L. & PNH (asymptomatic) & 24 & 60.3 & $\mathbf{M}$ & Negative & Negative & Negative \\
\hline D. L. & $\begin{array}{l}\text { PNH (hemoglobinuric } \\
\text { episode) }\end{array}$ & 24 & 59.1 & $\mathbf{M}$ & Negative & Negative & Negative \\
\hline D. M. & $\begin{array}{c}\text { PNH (chronic } \\
\text { hemolysis) }\end{array}$ & 80 & 37.3 & $\mathbf{F}$ & Negative & Negative & Negative \\
\hline F. G. & $\begin{array}{l}\text { Hematologically nor- } \\
\text { mal; peptic ulcer }\end{array}$ & 48 & 65.9 & M & Negative & Negative & Negative \\
\hline
\end{tabular}

* Detailed results of direct Coombs test titrations are given in Table IV.

mained. There was a corresponding increase in urinary excretion rate since from 84 to $89 \%$ of the recovered radioactivity was recovered in the 1 st $24 \mathrm{hr}$. There was no significant difference between the two normal persons and patient A. F. The fractional catabolic rate of $\mathrm{C}^{\prime} 3 \mathrm{i}$ was 33 and $34 \%$ / $\mathrm{hr}$ for the two normal subjects and was $42 \% / \mathrm{hr}$ for patient A. F.

The data of a representative study is illustrated in Fig. 6. The later component with a longer plasma disappearance half-life represents only a small percentage of the labeled protein and could be due to residual $\mathrm{C}^{\prime} 3$ (not converted to $\mathrm{C}^{\prime} 3 \mathrm{i}$ in vitro).

\section{DISCUSSION}

The present study provides data concerning the metabolism of $\mathrm{C}^{\prime} 3$ and $\mathrm{C}^{\prime} 3 \mathrm{i}$ in normal individuals

TABLE IV

Direct Coombs Test Titrations of Patients with Hemolytic Anemia*

\begin{tabular}{|c|c|c|c|c|c|c|c|c|c|c|c|c|c|c|c|c|c|c|c|}
\hline \multirow[b]{2}{*}{ Subject } & \multirow[b]{2}{*}{ Diagnosis } & \multicolumn{6}{|c|}{ Anti-IgG } & \multicolumn{6}{|c|}{ Anti-C'3 } & \multicolumn{6}{|c|}{ Anti-C'4 } \\
\hline & & 4 & 16 & 64 & 256 & 1024 & 4096 & 6 & 12 & 24 & 48 & 96 & 192 & 6 & 12 & 24 & 48 & 96 & 192 \\
\hline H. H. & $\begin{array}{l}\text { Idiopathic warm antibody } \\
\text { AIHA }\end{array}$ & 4 & 4 & 4 & 4 & 3 & 2 & 3 & 3 & 2 & 1 & 1 & 0 & 1 & 1 & 0 & 0 & 0 & 0 \\
\hline A. F. & $\begin{array}{l}\text { Idiopathic warm antibody } \\
\text { AIHA }\end{array}$ & 4 & 4 & 4 & 4 & 2 & 1 & 4 & 4 & 3 & 3 & 2 & 1 & 4 & 2 & 2 & 2 & 1 & 0 \\
\hline J. T. & $\begin{array}{l}\text { Warm antibody AIHA- } \\
\text { chronic active hepatitis }\end{array}$ & 3 & 2 & 1 & 1 & 0 & 0 & 4 & 3 & 3 & 3 & 2 & 1 & 3 & 2 & 1 & 1 & 0 & 0 \\
\hline M. M. & $\begin{array}{l}\text { Warm antibody AIHA- } \\
\text { lymphoma }\end{array}$ & 3 & 2 & 2 & 1 & $\mathbf{0}$ & 0 & 2 & 0 & 0 & 0 & 0 & 0 & 3 & 2 & 0 & 0 & 0 & 0 \\
\hline M. D. & $\begin{array}{l}\text { Idiopathic warm antibody } \\
\text { AIHA }\end{array}$ & 2 & 2 & 2 & 1 & 0 & $\mathbf{0}$ & 1 & 1 & 0 & 0 & 0 & 0 & 0 & 0 & 0 & 0 & 0 & 0 \\
\hline E. B. & $\begin{array}{l}\text { Idiopathic warm antibody } \\
\text { AIHA }\end{array}$ & 0 & 0 & 0 & 0 & 0 & 0 & 2 & 2 & 1 & 0 & 0 & 0 & 3 & 3 & 1 & 0 & 0 & 0 \\
\hline E. D. & $\begin{array}{l}\text { a-methyldopa-induced } \\
\text { warm antibody AIHA }\end{array}$ & 4 & 4 & 4 & 3 & 2 & $\mathbf{0}$ & 0 & $\mathbf{0}$ & 0 & 0 & 0 & 0 & 0 & $\mathbf{0}$ & 0 & 0 & 0 & 0 \\
\hline F. M. & $\begin{array}{l}\text { Idiopathic atypical cold } \\
\text { antibody AIHA }\end{array}$ & 0 & 0 & 0 & 0 & 0 & 0 & 4 & 4 & 4 & 4 & 3 & 1 & 4 & 4 & 4 & 3 & 2 & 0 \\
\hline D. L. & PNH & 0 & 0 & 0 & 0 & 0 & 0 & 0 & 0 & 0 & 0 & 0 & 0 & 0 & 0 & 0 & 0 & 0 & 0 \\
\hline D. M. & PNH & 0 & 0 & 0 & 0 & 0 & 0 & 0 & 0 & 0 & 0 & 0 & 0 & 0 & 0 & 0 & 0 & 0 & 0 \\
\hline
\end{tabular}

* Agglutination scored as 1 to 4 plus for each reciprocal of dilution of antisera. 
with Miscellaneous Disorders

\begin{tabular}{|c|c|c|c|c|c|c|c|}
\hline $\begin{array}{c}\text { Total } \\
\text { serum } \\
\text { complement }\end{array}$ & $\begin{array}{c}\text { Plasma } \\
\text { disappearance } \\
\text { half-life of } C^{\prime} 3\end{array}$ & $\underset{C^{\prime} 3}{\text { Serum }}$ & $\begin{array}{l}\text { Plasma } \\
\text { volume }\end{array}$ & $\begin{array}{c}\text { Total } \\
\text { Intravascular } \\
\text { C'3 pood }^{\prime} 3 \text {. }\end{array}$ & $\begin{array}{l}\text { Intravascular } \\
\text { dustribition }\end{array}$ & $\begin{array}{c}\text { Fractional } \\
\text { catabolic } \\
\text { rate }\end{array}$ & $\begin{array}{c}C^{\prime} 3 \text { systhesis } \\
\text { rate }\end{array}$ \\
\hline $\mathrm{C}^{\prime} \mathbf{H}_{\text {so }}$ units $/ m l$ & $h r$ & $m g / m l$ & $m g$ & $m g$ & $\begin{array}{c}\text { \% of total } \\
\text { pool }\end{array}$ & $\% / h r$ & $m g / k g$ per $h r$ \\
\hline 173 & 51 & 1.34 & 2443 & 3274 & 61 & 2.36 & 1.28 \\
\hline 119 & 52 & 1.49 & 2893 & 4311 & 70 & 1.96 & 1.30 \\
\hline 102 & 58 & 1.10 & 3408 & 3749 & 69 & 1.78 & 1.10 \\
\hline 142 & 39 & 1.26 & 3491 & 4399 & 67 & 2.91 & 2.17 \\
\hline 129 & 40 & 1.52 & 1865 & 2835 & 66 & 2.78 & 2.11 \\
\hline 259 & 54 & 1.95 & 2913 & 5680 & 66 & 2.13 & 1.84 \\
\hline
\end{tabular}

and in patients with acquired hemolytic anemias of diverse etiology. Important measurements of $\mathrm{C}^{\prime} 3$ metabolism derived from an isotope study as designed herein are the fractional catabolic rate and the synthesis rate for $\mathrm{C}^{\prime} 3$ corrected for body weight. The normal range (mean $\pm 2 \mathrm{SD}$ ) for the former is from 1.56 to $2.68 \% / \mathrm{hr}$ and for the latter $0.90-1.42 \mathrm{mg} / \mathrm{kg}$ per $\mathrm{hr}$. These values are in good agreement with those of Alper and Rosen (6).

The low levels of $C^{\prime} 3$ present in the patients with warm antibody AIHA with $\mathrm{C}^{\prime} 3$ on their erythrocytes in this series are not due to a decreased rate of synthesis of this portion. Indeed, the fractional catabolic rate of $C^{\prime} 3$ and the $C^{\prime} 3$ synthesis rate were either at the upper limit of normal or were distinctly above normal in each case (Fig. 3). The two patients with warm antibody AIHA with $C^{\prime}$ components on their erythrocytes whose values for $\mathrm{C}^{\prime} 3$ synthesis rate were just at the upper limit of normal were patients whose erythrocytes were only weakly coated with complement components, as judged by direct Coombs test titrations (see Table IV, patients M. M. and M. D.). The data also indicate that an increased rate of synthesis may maintain a normal $C^{\prime} 3$ level (patient A. F.).

The percentage of protein in the intravascular compartment was abnormally low in patient $\mathrm{H}$. $\mathrm{H}$. The urinary excretion rate in patient $\mathrm{H}$. $\mathrm{H}$. was not increased, suggesting sequestering of the
$\mathrm{C}^{\prime} 3$ in an "extravascular" pool. The most logical site in this patient with AIHA for such "extravascular" location of protein (i.e., outside the plasma) would be the erythrocytes but such localization could not be shown.

Presumably these negative findings reflect the fact that the fractional catabolic rate of $\mathrm{C}^{\prime} 3$ in patients was at most $2 \%$ above normal; if this increase represents that portion of $C^{\prime} 3$ reacting with autoantibody and erythrocytes, then only $2 \%$ of the $1 \mathrm{mg}$ (or less) that we injected so reacts per hr. Only $10 \%$ of $C^{\prime} 3$ (equal to about $20 \mu \mathrm{g}$ of injected $C^{\prime} 3-{ }^{125}$ I that is activated by an immune reaction on the surface of an erythrocyte adheres to the erythrocyte (the remainder being converted to $C^{\prime} 3 \mathrm{i}$ ) (4) and we counted only about $0.3 \%$ of the patient's red cell mass. Thus our sample could have a maximum of $0.006 \mu \mathrm{g}$ of $\mathrm{C}^{\prime} 3-^{125} \mathrm{I}$ after $1 \mathrm{hr}$. One would anticipate that this amount of $\mathrm{C}^{\prime} 3^{-125} \mathrm{I}$ might be detectable, particularly after continued reactivity during longer periods of time. However, as in the study of Alper and Rosen (6), our attempts to demonstrate labeled protein on the erythrocytes gave negative results in all studies. An additional consideration in evaluating the inability to detect labeled $\mathrm{C}^{\prime} 3$ on the red cells is the possibility of elution of the material after binding to red cells. No information is available concerning the stability of $C^{\prime} 3$ fixation to the erythrocyte in vivo in autoimmune hemolytic anemia. 
TABLE V

Hematologic and Serologic Data of

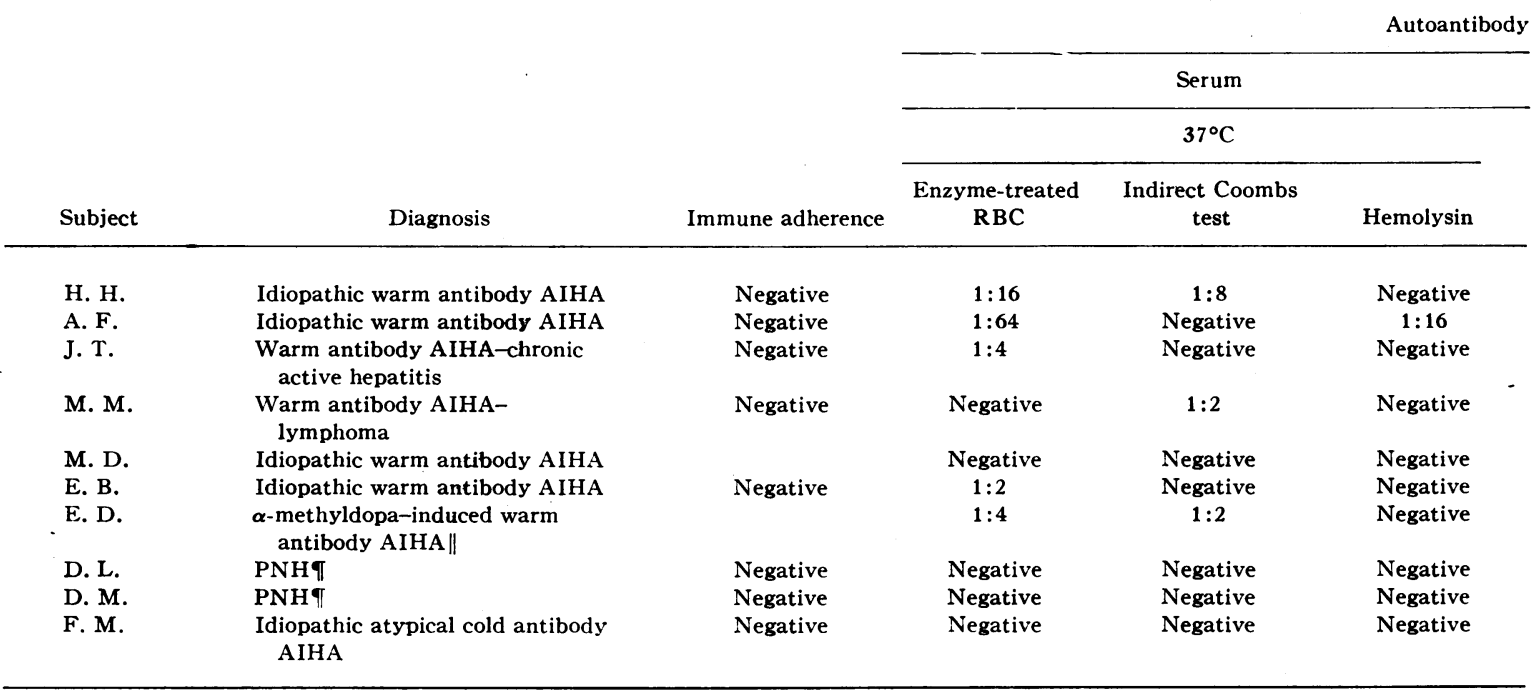

* Tests for specificity of the autoantibodies revealed anti-I specificity in serum F. M.; no Rh specificity was demonstrated in the cases of warm antibody AIHA.

$\ddagger$ Indirect Coombs test with eluate, positive using anti-IgG but negative using anti- $C^{\prime} 3$.

\& Indirect Coombs test with eluate, positive using anti-IgG or anti-C'3.

$\|$ Study done just after cessation of $\alpha$-methyldopa; the patient is now hematologically normia.

T Ham's test positive; sugar water test positive; urine hemosiderin positive.

** Titer of hemolysin at $23^{\circ} \mathrm{C}$ was $1: 16$.

The data concerning simultaneously studied subjects H. H., A. F., E. B., and B. C. demonstrated rapid removal of a significant portion of protein during the first $15 \mathrm{~min}$. Such rapid removal from the plasma may indicate an excessive rate of catabolism because of the patient's disease or may represent heterogeneity of the labeled protein as occurs with partial denaturation of a portion of the sample. The findings were not related to the patients' immunohemolytic anemias, as indicated by the fact that such a pattern of plasma disappearance of $\mathrm{C}^{\prime} 3{ }^{-125} \mathrm{I}$ occurred in the normal control B. C. as well as in the patients. Moreover, there was a continued excessive rate of plasma disappearance of the labeled protein until the plasma disappearance curve reached its final slope (Fig. 4). This is to be anticipated and indicates the presence of less severely denatured protein (29). If one were to include this excessive plasma disappearance during the 1 st day in calculations of the fractional catabolic rate, $\mathrm{C}^{\prime} 3$ synthesis rate, and the ratio of extravascular to intravascular pools, erroneously high values would be obtained. ${ }^{3}$ The data of Alper and Rosen (6)

3 With such data, calculated from curves derived from the percentage of radioactivity in the $15 \mathrm{~min}$ specimen, on patients S. T. and M. J. K. is therefore open $w$ question unless information on simultaneously studied normal individuals is available.

Some immunohemolytic anemias such as $\mathrm{Rh}$ hemolytic disease of the newborn, and isoimmune transfusion reactions involving $\mathrm{Rh}$ antibodies, rarely, if ever, involve the fixation of complement to erythrocytes. In about $50 \%$ of cases of idiopathic warm antibody AIHA $(32,33)$ and in all reported AIHA cases associated with $\alpha$-methyldopa administration $(34,35)$, erythrocytes are coated with IgG but not with complement components. In one such patient studied here (patient E. D.), all measurements of complement metabolism were normal.

Elevated levels of serum complement are known to occur as an acute phase reactant in a wide variety of disorders in which inflammation occurs, including pyogenic infections, polyarthritis, and the fractional catabolic rates for subjects H. H., A. F., E. B., and B. C. were $8.02,7.44,5.39$, and $3.76 \% / \mathrm{hr}$, respectively; $\mathrm{C}^{\prime} 3$ synthesis rates were $2.63,3.86,2.15$, and $2.29 \mathrm{mg} / \mathrm{kg} \mathrm{per} \mathrm{hr}$; and the percentage of protein in the I.V. pool $35,41,51$, and $41 \%$. If one uses a "corrected plasma volume" (6) in such calculations, one also includes the $C^{\prime} 3{ }^{-125} \mathrm{I}$ removed during the 1 st $15 \mathrm{~min}$ and thus derives an even higher fractional catabolic rate. 


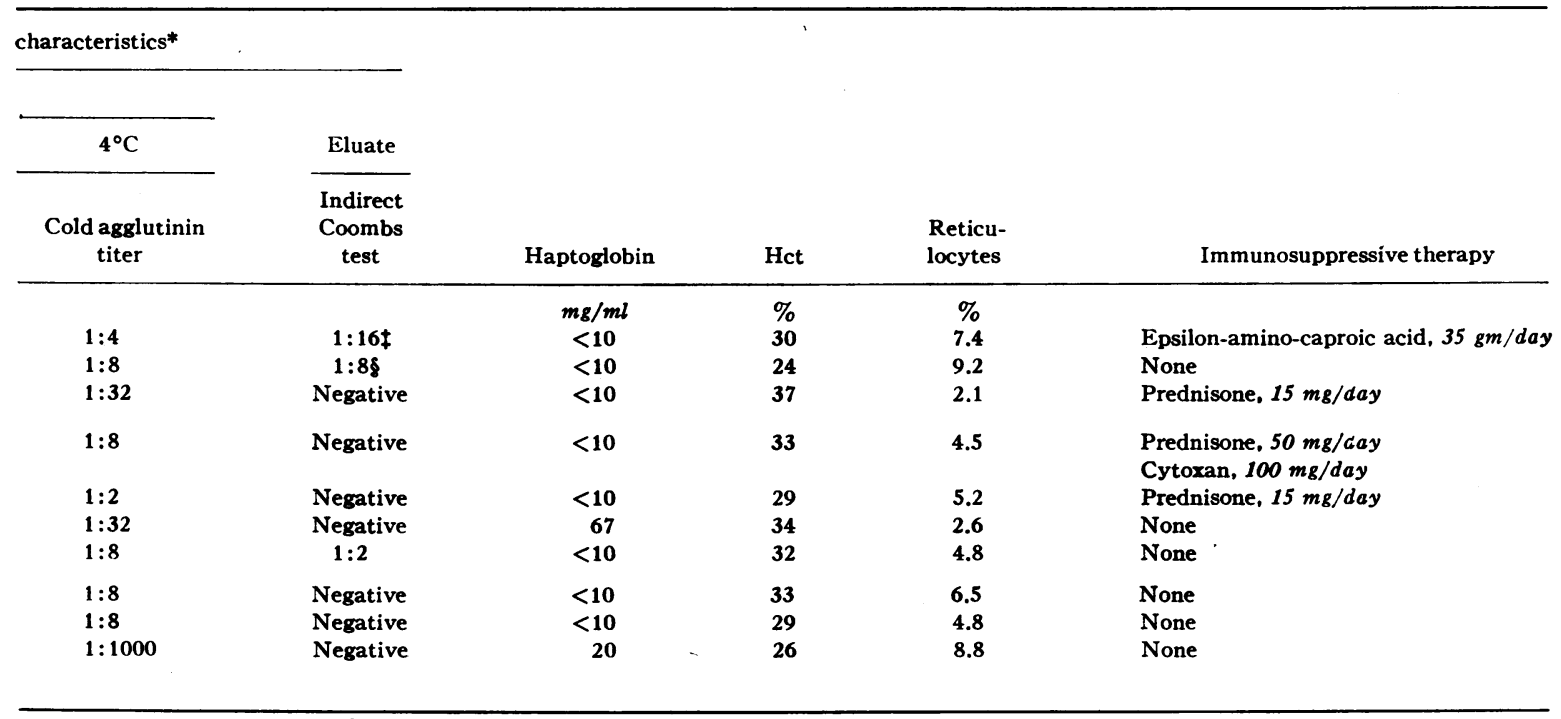

myocardial infarction (36). Patient F. G. was studied as a hematologically normal subject, but had a healing peptic ulcer; he had elevated levels of $C^{\prime}$ and $C^{\prime} 3$. The isotope study revealed normal values for plasma disappearance half-life of $\mathrm{C}^{\prime} 3$ and for the extravascular/intravascular pool ratio, but the $C^{\prime} 3$ synthesis rate was elevated. Thus the elevated serum $\mathrm{C}^{\prime} 3$ was due to an increased rate of synthesis of the protein and not to a decreased. rate of catabolism.

Both patients with $\mathrm{PNH}$ had distinctly elevated rates of synthesis of $C^{\prime} 3$ when symptomatic although patient $D$. L. had normal values at a time when his disease was in relative remission. Although only late reacting complement components (those reacting after $\mathrm{C}^{\prime} 3$ ) are necessary for in vitro lysis of $\mathrm{PNH}$ erythrocytes $(27,37)$, it nevertheless appears that activated $\mathrm{C}^{\prime} 3$ may be utilized for in vivo lysis. Alternatively, activated $C^{\prime} 3$ may be important for the conversion of the later reacting complement components to a hemolytically active form, thus indirectly playing a role in lysis of $\mathrm{PNH}$ erythrocytes (2).

The three studies done with $C^{\prime} 3 i$ merit special comment. The labeled protein was removed from the plasma very rapidly with only $10 \%$ or less remaining after $2 \mathrm{hr}$. Since $90 \%$ of $\mathrm{C}^{\prime} 3$ that reacts with erythrocyte bound $\mathrm{C}^{\prime} 4,2 \mathrm{a}$ complexes remains in the fluid phase as $C^{\prime} 3 \mathrm{i}$ rather than being fixed to the cell (4), one would anticipate that in vivo participation of $\mathrm{C}^{\prime} 3$ in immune reactions would be detectable by a study of isotope-labeled $C^{\prime} 3$ only if $\mathrm{C}^{\prime} 3 \mathrm{i}$ or the other conversion products of $\mathrm{C}^{\prime} 3$ were catabolized at a comparatively faster rate than native $C^{\prime} 3$. The very short plasma disappearance half-life of $\mathrm{C}^{\prime} 3 \mathrm{i}$ in the three persons studied is thus consistent with our findings of a short plasma disappearance half-life of $\mathrm{C}^{\prime} 3$ in patients with AIHA and $C^{\prime} 3$ on their erythrocytes.

Furthermore, the rapid rate of catabolism of $\mathrm{C}^{\prime} 3 \mathrm{i}$ is consistent with the fact that only trace quantities of $C^{\prime} 3$ reaction products are detectable in the serum of patients with hypocomplementemia and low $C^{\prime} 3$ concentration. The excellent studies of West et al. $(38,39)$ showed only small amounts of $\alpha_{2 \mathrm{D}}$-globulin $\left(\mathrm{F}(\mathrm{d}) \mathrm{C}^{\prime} 3\right)$ and $\beta_{1 \mathrm{~A}}$-globulin (F.(c) $\mathrm{C}^{\prime} 3$ ) in severely hypocomplementemic patients with glomerulonephritis. Other reports of small amounts of breakdown products of $\mathrm{C}^{\prime} 3$ in the circulation are those of Morse, (40), Lachmann (41), Soothill (42), and Alper and Rosen (6). 


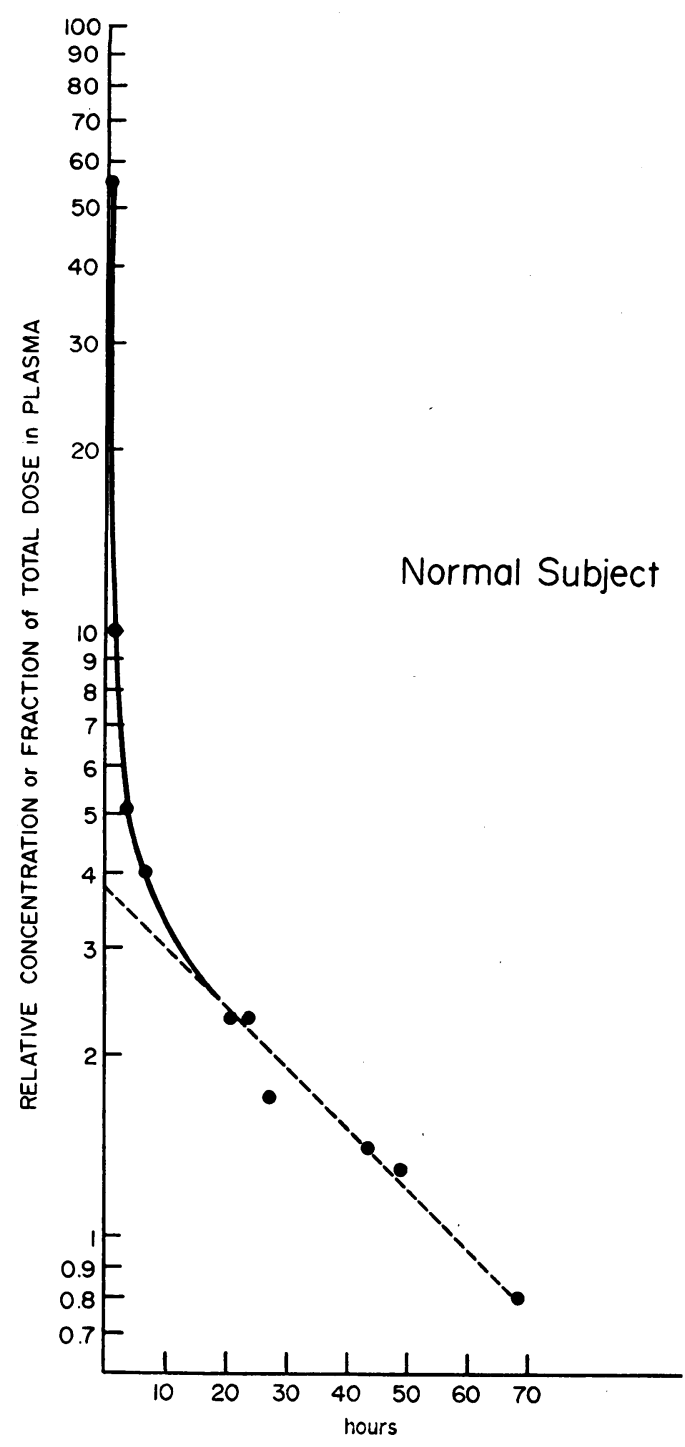

Figure 6 Plasma disappearance curve of $\mathrm{C}^{\prime} 3 \mathrm{i}^{-125} \mathrm{I}$ in a normal subject. Note that only $47 \%$ of the injected protein remained in the plasma after $15 \mathrm{~min}$ and that less than $10 \%$ remained after $2 \mathrm{hr}$.

None of our patients were hypocomplementemic to a degree comparable to the patients of West et al. (38). Fresh plasma obtained from our mildly to moderately hypocomplementemic patients contained no demonstrable $\alpha_{2 \mathrm{D}}, \beta_{1 \mathrm{~A}}$, or $\mathrm{C}^{\prime} 3 \mathrm{i}$ by immunoelectrophoresis when tested with antiserums specific for these antigens. ${ }^{4}$

Two other facts concerning the reactivity of $\mathrm{C}^{\prime} 3$

${ }^{4}$ This includes antiserum generously supplied by $\mathrm{Dr}$. Clark West in addition to antisera developed in our own laboratories. in AIHA merit emphasis, since little information is available concerning the biologic activity or functional significance of $\mathrm{C}^{\prime} 3$ that is bound to erythrocytes in vivo in AIHA. Most important is the previously reported observation (43) that erythrocytes from patients with AIHA that have $\mathrm{C}^{\prime} 3$ on the membrane surface, as judged by a strongly reactive direct Coombs test with anti-C'3 sera, are nevertheless negative in immune adherence (Table V). Since immune adherence is a sensitive test for the detection of hemolytically active erythrocyte bound $C^{\prime} 3$ (4), the negative result indicates a qualitatively different state of the fixed protein to the erythrocyte surface. This could be due to decay of the functional activity of the protein.

In addition, we have observed that eluates from erythrocytes sensitized in vivo with IgG and C'3 may be able to sensitize normal erythrocytes not only with IgG but also with $\mathrm{C}^{\prime} 3$ (Table V). It is probable that the $\mathrm{C}^{\prime} 3$ of patient $\mathrm{A}$. F. was partially bound to antibody and for this reason transferred with the antibody to normal erythrocytes (44-46).

Finally, in reviewing the in vitro reaction mechanism of $\mathrm{C}^{\prime} 3$ (4) in light of our isotope studies, we would like to propose that also in vivo $C^{\prime} 3$ when activated by the $C^{\prime} 4,2 \mathrm{a}$ complex, may either become bound to a cell surface or be converted to $\mathrm{C}^{\prime} 3 \mathrm{i}$; the conversion of $\mathrm{C}^{\prime} 3$ and the rapid catabolism of $\mathrm{C}^{\prime} 3 \mathrm{i}$ tend to cause low concentrations of $\mathrm{C}^{\prime} 3$ in the serum, resulting in a compensatory increased rate of synthesis of $\mathrm{C}^{\prime} 3$ which in some cases is able to maintain normal serum $C^{\prime} 3$ levels.

Our data strengthen the concept that serum complement participates in immune reactions in vivo. Studies to determine whether it plays an important role in the pathogenesis of human hemolytic disease are currently in progress, as are studies of the metabolism of $\mathrm{C}^{\prime} 3$ and other complement components in other human diseases.

\section{ACKNOWLEDGMENTS}

We wish to express our appreciation to Dr. Ralph Cavalieri for generous assistance throughout the study, to Dr. Ben L. Hom for a critical review of the isotope data, and to $\mathrm{Mr}$. James Castle for his assistance with four of the figures.

Dr. Petz was a recipient of a Dernham Senior Fellowship in Oncology of the California Division of the American Cancer Society. These studies were carried 
out in part on the General Clinical Research Center Ward, University of California, FR-79, provided by the Division of Research Facilities and Resources, U. S. Public Health Service: and were supported in part by grants 1 R 01 A108188-01 HEM, Hematology training grant $\mathrm{HE}$ 5677, research grant $\mathrm{HE}$ 5997, the Lederle Laboratories Division of American Cyanamid Company, and American Heart Association grant G5-G-166.

\section{REFERENCES}

1. Müller-Eberhard, H. J., U. R. Nilsson, A. P. Dalmasso, M. J. Polley, and M. A. Calcott. 1966. A molecular concept of immune cytolysis. Arch. Pathol. 82: 205.

2. Müller-Eberhard, H. J. 1968. Chemistry and reaction mechanisms of complement. Advan. Immunol. 8: 2.

3. Polley, M. J., and H. J. Müller-Eberhard. 1966. Chemistry and mechanism of action of complement. Progr. Hematol. 5: 1.

4. Müller-Eberhard, H. J., A. P. Dalmasso, and M. A. Calcott. 1966. The reaction mechanism of $\beta_{1 \mathrm{c}}$-globulin $\left(\mathrm{C}^{\prime} 3\right)$ in immune hemolysis. J. Exptl. Med. 123: 33.

5. Alper, C. A., A. S. Levin, and F. S. Rosen. 1966. Beta-1e-globulin: metabolism in glomerulonephritis. Science. 153 : 180.

6. Alper, C. A., and F. S. Rosen. 1967. Studies of the in vivo behavior of human $\mathrm{C}^{\prime} 3$ in normal subjects and patients. J. Clin. Invest. 46: 2021.

7. Rapp, H. J., and T. Borsos. 1963. Complement and Hemolysis. Science. 141: 738.

8. Müller-Eberhard, editor. 1966. Summary of the La Jolla Complement Workshop. Immunochemistry. 3: 495.

9. Bokisch, V. A., D. B. Budzko, H. J. Müller-Eberhard, and C. G. Cochrane. 1968. Cleavage of human $\mathrm{C}^{\prime} 3$ by trypsin into three antigenically distinct fragments including anaphylatoxin. Federation Proc. 27: 314. (Abstr.)

10. West, C. D., N. C. Davis, J. Forristal, J. Herbst, and R. Spitzer. 1966. Antigenic determinants of human $\beta_{1 \mathrm{e}^{-}}$and $\beta_{1 \mathrm{G}}$-globulins. J. Immunol. 96: 650 .

11. Dacie, J. V. 1962. The Haemolytic Anaemias; Congenital and Acquired. J. \& A Churchill, Ltd., London. 2nd edition. 2: 343.

12. Kabat, E. A., and M. M. Mayer. 1961. Exper. Immunochemistry. Charles C Thomas, Springfield. 2nd edition. 149.

13. Mancini, G., A. O. Carbonara, and J. F. Heremans. 1965. Immunochemical quantitation of antigens by single radial immunodiffusion. Immunochemistry. 2: 235.

14. Harboe, M., H. J. Müller-Eberhard, H. H. Fudenberg, M. J. Polley, and P. L. Mollison. 1963. Identification of the components of complement participating in the antiglobulin reaction. Immunology. 6: 412.

15. Nilsson, U. R., and H. J. Müller-Eberhard. 1965. Isolation of $\beta_{1 F}$-globulin from human serum and its characterization as the fifth component of complement. J. Exptl. Med. 122: 277.
16. Lowry, O. H., N. J. Rosebrough, A. L. Farr, and R. J. Randall. 1951. Protein measurement with the Folin phenol reagent. J. Biol. Chem. 193: 265.

17. Kabat, E. A., and M. M. Mayer. 1961. Experimental Immunochemistry. Charles C Thomas, Springfield. 2nd edition. 480.

18. Dacie, J. V., and S. M. Lewis. 1963. Practical Haematology. Grune and Stratton, Inc., New York. 3rd edition. 133.

19. Müller-Eberhard, H. J., and C. E. Biro. 1963. Isolation and description of the fourth component of human complement. J. Exptl. Med. 118: 447.

20. Campbell, D. H., J. S. Garvey, N. E. Cremer, and D. H. Sussdorf. 1963. Methods in immunology: a laboratory text for instruction and research. Benjamin, N. Y.

21. Landsteiner, K., C. P. Miller, Jr. 1925. Serological studies on the blood of primates. II. The blood groups in anthropoid apes. J. Exptl. Med. 42: 853.

22. Rubin, H. 1963. Antibody elution from red blood cells. J. Clin. Pathol. 16: 70.

23. Nelson, D. S. 1963. Immune adherence. Immunology. 3: 131.

24. Owen, J. A., F. C. Better, and J. Hoban. 1960. A simple method for the determination of serum haptoglobins. J. Clin. Pathol. 13: 163.

25. Hartmann, R. C., and D. E. Jenkins, Jr. 1966. The "Sugar-water" test for paroxysmal nocturnal hemoglobinuria. Nez' Engl. J. Med. 275: 155.

26. Heremans, J. 1960. Les globulins sériques du système gamma; leur nature et leur pathologie. Editions Arscia S.A., Bruxelles.

27. Müller-Eberhard, H. J., M. J. Polley, and M. A. Calcott. 1967. Formation and functional significance of a molecular complex derived from the second and the fourth component of human complement. J. Exptl. Med. 125: 359.

28. Donato, L., C. M. E. Matthews, B. Nosslin, G. Segre, and F. Vitek. 1966. Applications of tracer theory to protein turnover studies. J. Nucl. Biol. Med. 9: 3.

29. Andersen, S. B. 1964. Metabolism of Human Gamma Globulin ( $\left.\gamma_{s s-g l o b u l i n}\right)$. F. A. Davis Company, Philadelphia.

30. Andersen, S. B. 1965. Calculation of plasma protein metabolism by Nosslin's general mathematical model. In Physiology and Pathophysiology of Plasma Protein Metabolism. H. Koblet, P. Vesin, H. Diggelmann, and S. Barandun, editors. 111. Huber, Berne.

31. Williams, D. E., and R. A. Reisfeld. 1964. Disc electrophoresis in polyacrylamide gels: extension to new conditions of $\mathrm{pH}$ and buffer. Ann. N. Y. Acad. Sci. $121: 373$.

32. Dacie, J. V. 1962. The Haemolytic Anaemias; Congenital and Acquired. J. \& A. Churchill, Ltd., London. 2nd edition. 2: 432.

33. Worlledge, S. M. 1965. Serological aspects of autoimmune haemolytic anaemia. In Autoimmunity, A Symposium of the 5th Congress of the International Academy of Pathology. R. W. Baldwin and J. H. 
Humphrey, editors. Blackwell Scientific Publications, Oxford. 52.

34. Worlledge, S. M., K. C. Carstairs, and J. V. Dacie. 1966. Autoimmune haemolytic anaemia associated with $\alpha$-methyldopa therapy. Lancet. 2: 135.

35. LoBuglio, A. F., and J. H. Jand1. 1967. The nature of the alpha-methyldopa red-cell antibody. New Engl. J. Med. 276: 658 .

36. Townes, A. S. 1967. Complement levels in disease. Johns Hopkins Med. J. 120: 337.

37. Yachnin, S. 1965. The hemolysis of red cells from patients with paroxysmal nocturnal hemoglobinuria by partially purified sub-components of the third complement component. J. Clin. Invest. 44: 1534.

38. West, C. D., S. Winter, J. Forristal, J. M. McConville, and N. C. Davis. 1967. Evidence for in vivo breakdown of $\beta_{1 \mathrm{c}}$-Globulin in hypocomplementemic glomerulonephritis. J. Clin. Invest. 46: 539.

39. West, C. D., S. Winter, J. Forristal, and N. C. Davis. 1968. Effect of ageing of serum on consumption of antibody by $\beta_{1 \mathrm{c}}$-globulin determinants; evidence for circulating breakdown products in glomerulonephritis. Clin. Exptl. Immunol. 3: 57.

40. Morse, J. H., H. J. Müller-Eberhard, and H. G. Kunkel. 1962. Antinuclear factors and serum comple- ment in systemic lupus erythematosus. Bull. N. $Y$. Acad. Med. 38: 641 .

41. Lachmann, P. J. 1963. Complement. In Clinical Aspects of Immunology. P. G. H. Gell and R. R. A. Coombs, editors. Blackwell Scientific Publications, Oxford. 260.

42. Soothill, J. F. 1967. Altered complement component $\mathrm{C}_{3 \Delta}^{\prime}\left(\boldsymbol{\beta}_{1 \mathrm{c}}-\boldsymbol{\beta}_{1 \mathrm{~A}}\right)$ in patients with glomerulonephritis. Clin. Exptl. Immunol. 2: 83.

43. Fink, D. F., L. D. Petz, and H. H. Fudenberg. 1966. The immune adherence reaction as a means of detecting complement sensitization of human erythrocytes. Proc. Intern. Congr. Intern. Soc. Haematol., 11th, Sydney, 309. (Abstr.)

44. Leddy, J. P., R. F. Bakemeier, and J. H. Vaughan. 1965. Fixation of complement components to autoantibody eluted from human RBC. J. Clin. Invest. 44: 1066. (Abstr.)

45. Eyster, M. E., D. E. Jenkins, Jr., and W. H. Moore. 1967. Antibody eluates in patients with positive antiglobulin reactions. Clin. Res. 15: 275. (Abstr.)

46. Vos, G. H., L. D. Petz, and H. H. Fudenberg. Specificity of acquired haemolytic anaemia autoantibodies and their serological distribution. Brit. J. Haemat. In Press. 